\title{
PRINCESS ELIZABETH BIBESCO: A NOVELIST OF THE 1920S
}

\author{
Mihaela Mudure \\ Babeş-Bolyai University (Romania)
}

\begin{abstract}
Princess Elizabeth Bibesco (1897-1945) was the daughter of Sir Herbert Henry Asquith, Prime Minister of Great Britain between 1908 and 1916, and wife of Prince Antoine Bibesco (1878-1951). During the 1920s Bibesco published two novels The Fir and the Palm and There Is No Return which include her into the same spiritual family as the literary impressionists of the time. Critics did not pay too much attention to this novelist of the $1920 \mathrm{~s}$ who holds, however, a singular place in the literary life of the time. This paper is a close reading of Bibesco's novels from the 1920 which proves her indebtedness to modernism and literary impressionism.
\end{abstract}

KEYwords: Elizabeth Bibesco, literary impressionism, novel, psychology, style, paradox.

\section{LA PRINCESA ELIZABETH BIBESCO: \\ UNA NOVELISTA DE LA DÉCADA DE LOS AÑOS VEINTE}

\section{RESUMEN}

La princesa Elizabeth Bibesco (1897-1945) era la hija de Sir Herbert Henry Asquith, Primer Ministro del Reino Unido entre 1908 y 1916, y la esposa del príncipe Antoine Bibesco (1878-1951). Durante la década de los años veinte Bibesco publicó dos novelas The Fir and the Palm y There Is No Return, que la sitúan en la misma familia espiritual que los impresionistas de su tiempo. La crítica no prestó demasiada atención a esta novelista de los años veinte, que, sin embargo, ocupó un lugar especial en la vida literaria de su tiempo. Este trabajo consiste en una lectura detallada de las novelas de Bibesco que muestra su deuda con el modernismo y el impresionismo literario.

Palabras Clave: Elizabeth Bibesco, impresionismo literario, novela, psicología, estilo, paradoja. 
Elizabeth Bibesco (1897-1945) was born in an illustrious family of the British aristocracy. Her father, Herbert Asquith, was Prime Minister of Great Britain from 1908 till 1916. Her mother, Margot Asquith, was a well-known socialite of in between wars Britain. In 1919 she got married to Antoine Bibesco (1878-1951) who at that time was Romania's diplomatic representative in London. Proust writes in Patiches et mélanges: "Miss Asquith who was probably the most intelligent of all and looked like one of those beautiful figures from the frescoes one can see in Italy, got married to Prince Antoine Bibesco who had been the idol of those where he had lived. The wedding was very popular and there were cheers from everywhere" $(1919,35){ }^{1}$ It was not a happy marriage. The age difference as well as Bibesco's sexual preferences ${ }^{2}$ finally made Elizabeth look for consolation in other men's arms $s^{3}$ or in alcohol.

Elizabeth seconded her husband in his diplomatic missions in Madrid and Washington DC. In 1939, when World War II broke out, the Bibescos were in Romania. Romania joined the Axis (the alliance of Germany and Italy) hoping to get back the territories ceded to the Soviet Union in 1940. On 10 February 1941 Great Britain cut its diplomatic relations with Romania and on 6 December 1941 it declared war on Romania. Elizabeth Bibesco's daughter, Priscilla Bibesco, left Romania and, according to Anita Leslie, she hitchhiked through Europe and finally reached Lebanon where she worked as a journalist (See Blow 2004). It was a cover up job for her affiliation with the Secret Service. It was only at the end of World War II that she could reach Britain by ship and be reunited with Margot Asquith, her grand-mother, who died shortly afterwards, on 28 July 1945 . Elizabeth and her daughter never got reunited. Nor would Elizabeth witness the Allies' victory. She died in April 1945 while listening to war news on BBC. ${ }^{4}$ Maurice Schumann sums up very adequately the tragedy of Elizabeth's life: "Extravagant, generous and liberal, Elizabeth seemed to foresee the cruelty of her destiny: she was to die in a Romania forced to join the camp of her country's enemies and she was never to see again the flowers from Kew Gardens or the apses of Notre Dame" (1984, 3-4).

1 "Mlle Asquith qui était probablement la plus intelligente d'aucuns et semblait une de ces belles figures peintes à fresque ce qu'on voit en Italie, épousa le prince Antoine Bibesco qui avait été l'idole de ceux où il avait résidé. Ce mariage fut grand bruit et partout d'applaudissements." (All French quotations have been translated by Mihaela Mudure).

${ }^{2}$ Guillaume Apollinaire's erotic novel Les Onze Mille Verges ou les amour d'un hospodar seems to have been inspired by Bibesco's reckless life. One of the main characters is a priapic Wallachian aristocrat with strange erotic tastes.

${ }^{3}$ One of the best known such episodes was Bibesco's romance with John Middleton Murry. According to Brindle, "Bibesco was cultivating Murry with a view to publishing her work in the Athenaeum, and Mansfield disapproved of this in no uncertain terms, believing Bibesco and her work to be trite and of little artistic merit" $(2020,19)$. Katherine Mansfield sent Bibesco a short and blunt letter asking her to cut short any dalliances with Murry.

${ }^{4}$ See New York Times, 9 April 1945.

5 "Extravagante, généreuse et libérale, Elizabeth semblait pressentir la cruauté de son destin: elle devait mourir au coeur d'une Roumanie jetée par contraints dans le camps des ennemis de son pays natal sans avoir revu les fleurs de Kew Gardens ni l'abside de Notre Dame." 
The 1920s are the period when Europe and the world tried to heal after the suffering of the war. Life must be lived at its best. The aristocracy was in decay and its refined life style became more and more a museum exhibit. New social forces arose. The people wanted leaders who grew up in modest milieus whose charisma and populist discourse could mesmerize and make one forget the ills of the day. Mussolini was such an example for the sympathizers of the right. Lenin and his Bolshevik comrades gave false hopes to those who thought the left was the solution. Both Lord Asquith and his daughter, Princess Elizabeth Bibesco, saw these developments with a worried eye. ${ }^{6}$ Already in the 1920 s they became involved in social work and would offer assistance to the political refugees that would flood to England from the countries with totalitarian regimes (Italy and, then, Austria and Germany) (See Grenville and Reiter 2011).

For Elizabeth, the conservative and the extreme right political movements of the time went hand in hand with women's oppression. Although she was not an explicit feminist, she disagreed with the totalitarian leaders who thought that woman was just a biological machine to produce the offspring of the nation. In 1928 British women over the age of 21 were granted the right to vote by the Representation of the People Act. Elizabeth was not too enthusiastic. She knew the behind-the-scenes of British politics, she had noticed the social and political imbalance between man and woman, the inequality of chances, woman's marginalization, but she was not sure that century-old mentalities could be changed overnight.

Her literary aspirations, her desire to enter the public space relying on the authority of literary authorship shows that she disagrees with the stereotypical tenets about woman's modesty. A woman author is a woman who defies the traditional separation between the male public space and the female private space. Elizabeth Bibesco started writing at an early age. ${ }^{7}$ In the 1920 s she was very active on the literary scene. Actually, she continued the spirit of the literary sorority that was very visible at the turn of the twentieth century: Mary Elizabeth Braddon (1835-1915), Ouida (1839-1908), Emily Gerard (1849-1905), Dorothea Gerard (1855-1915), or

${ }^{6}$ Priscilla Hodgson, Elizabeth and Antoine Bibesco's daughter, related an episode relevant for the Asquiths's attitude towards these new populist leaders of the European extreme right. In 1920, Margot Asquith, Priscilla's grandmother and Elizabeth's mother is received by Mussolini. The Duke received her "in his immense study wearing a riding suit and boots that had previously been shined with wax" ["dans son immense bureau en culottte de cheval avec de bottes admirablement cirés"] (1975, 103). Upon leaving, Margot Asquith, the wife of a former British Prime Minister, is asked by an army of journalists. What impression did the Duke make upon her? Margot Asquith answered dryly: "I don't like men who ride indoors" (103).

7 Muica considers that Elizabeth was influenced in taking up literature by her husband, a sophisticated Francophile Romanian boyard, whose mother, Hélène Bibesco, had a famous salon in Paris $(2017,35)$. As Elizabeth grew up in an intellectual environment where literary preoccupations were common, it is more accurate to say that her husband stimulated and encouraged her to keep writing. 
Rita Gollan ${ }^{8}$ (1850-1938) are among these minor(ized) female writers who belonged to a well-off elite but whose lives did not lack constraints.

Bibesco was also considered a woman spoiled by fate, an amateur who dabbled in literature in order to avoid the boredom of a rich life where there were no needs, only desires quickly to be satisfied. She tried to get in touch with the members of the illustrious Bloomsbury Circle: Virginia Woolf, Leonard Woolf, Katherine Mansfield or John Middleton Curry, but she was not accepted. They did not consider that Bibesco took literature seriously enough. Still, her literary method is not without connection with a predecessor of the Bloomsbury modernists: Henry James. Bibesco also relies on a central reflector and is painfully aware that life is just a beautiful golden bowl with a crack. Like Edith Wharton, Bibesco writes about the upper class women who can afford to translate the actual experience of living into complex analytical exercises. A convinced city lover, Bibesco's writing impresses by her fresh and salient observations. She is a subtle ironist and considers that only irony can make life acceptable and endurable.

Undoubtedly, Bibesco was aware of the peculiarities of literary impressionism as practised by Virginia Woolf, Katherine Mansfield, or Marcel Proust. It is well known that the great French novelist often confided in his good friend Antoine Bibesco. In a letter quoted by Paul Vernière, Proust wrote to Antoine Bibesco: "I think that it is only to the involuntary memories that the artist should demand the raw material of his work (apud Vernière 1971, 946). ${ }^{9}$ After her marriage to Antoine Bibesco, the young Elizabeth also became a member of the exclusivist circle of Marcel Proust's intimate friends. Like Proust, "Antoine Bibesco had chosen to turn his life into a work of art" (Palewski 1974, 123). From this point of view, the Bibesco spouses shared the same existential views and the same good taste. They abhorred washing the dirty laundry of their matrimony in public. Appearances had to look nice, whatever happened behind closed doors was supposed to stay there for ever. Marthe Bibesco also talks extensively in her writings about the friendship Marcel Proust had for François Mauriac, for Elizabeth and Antoine Bibesco. For instance, in an article published in Revue des Deux Mondes, Marthe Bibesco melancholically describes the house "where, towards the end of his life, Marcel Proust came to meet Elizabeth Asquith, Antoine's fiancée, and where Mauriac often came after his meeting under the Coupole ${ }^{10}$ on Thursday" $(1970,541) .{ }^{11}$

During the 1920s Elizabeth Bibesco wrote two novels: The Fir and the Palm (1924) and There Is No Return (1927). Both novels are good samples of modernist sensibility grafted on cosmopolitan and intimate life experiences. She wrote about

\footnotetext{
${ }^{8}$ Eliza Margaret Jane Humphreys.

9 “Je crois que ce n'est guère qu'aux souvenirs involontaires que l'artiste devrait demander la matière première de son oeuvre."

${ }_{10}$ The Coupole built by Jean Alaux for the meeting room of the French Senate, in the Palace of Luxemburg.

11 "où Marcel Proust est venu à la fin de sa vie pour faire la connaissance avec la fiancée d'Antoine, Elizabeth Asquith, où Mauriac venait parfois jeudi après la séance sous la Coupole."
} 
the world that she knew best, the elite of her time, but her existential conclusions are universal because of her unique capacity to grasp truths that belong to us all.

The Fir and the Palm is a social comedy populated with aristocrats, diplomats, bourgeois men and women who meet at cocktails, tea parties or official dinners. The novel has a circular structure marked by Jean, the valet, "the deputy of fate, she called him - announcing lunch in tones which showed without a possibility of doubt that life is a well-regulated, ordered state and destiny, a benign force over which we have no control" (Bibesco 1924, 7).

An erotic triangle (Helen-Toby-Cyril) evolved against the background of the salon gossip and idle conversation. Some remarks are louder and they point to the rising anti-Semitism of the upper classes. Count Schröding proudly announces that Disraeli "was the only Jew he had ever dined with" (95). Comments where irony and ignorance are difficult to distinguish refer to international political evolutions, such as the rise of Bolshevism. "Lady Horsham is sure that all women in Russia have been nationalized" (146). Although she was raised in a world where the force of the British colonial empire was revered, Bibesco mocks at the illusionary colonial superiority exhibited by the upper class. "'My husband believed in the Empire,' explained Lady Raeburn; 'we always called Indians 'niggers.' So foolish, don't you think? and quite unnecessary. Fortunately he never went there or it would have been almost rude" (120). There is also an implicit orientalism in these conversations relying on rich metaphors. The Ambassador, another member of Helen's circle, considers that "The East ... is a corridor of half-open doors" (202).

Guests cannot help noticing "the white flame of Cyril's intellect which so pierced through his conversation that when he talked, his words seemed like alabaster through which light was shining" (58). Cyril compliments Helen upon her charm. Their guests are fascinated by the lady of the house. As Cyril says, "Some of them seemed to dive into your eyes and some to skate over them" (180). Metaphors for time and flow of life abound: "each anemone you want to keep is a demand on spring to stay for ever" (156).

The same characters meet again and again in different settings, they dissect the world they live in and tragically feel the emptiness of their lives. Discretion, lack of achievement, waste, these are their main features. Only random amours can give some excitement to these people whose refinement hides a genuine incompetence for living life plentifully. Helen and Cyril Baldwin, Lady Horsham, Helen's mother-in-law, Toby Ross, Helen's lover, Lady Alicia Raeburn, Ariadne Amberley, Christopher Tyldesley, Selina Cathcart, Ann Wendover, Netta Carstairs, or Virginia Sterling and Mathew, her lover, are rather variants of the same human type. They spend their time trying to find a meaning to life and in life. What is life and how can it be experienced to make the most of it? For Virginia life is a rack, one must conform to a code: "[I]f life is to be played as a game, an iron code has to be observed" (207). Selina Cathcart evaluates another existential strategy: "In fact ... you safeguard your emotions by having affairs without caring in order to insure against feeling?” (209). Bibesco's capacity to depict silhouettes is remarkably pictorial and always accompanied by a subtle touch of irony. Here is, for instance, Mrs Carstairs: "Even the most billowy summery clothes contrived to look tight on 
her, her lightest, most flowery hats managed to look heavy. A butterfly in youth, she had become a mosquito in middle age with the remnants of militant charm aggravated by fussiness" (16).

The meanders of salon conversation are spiced with witty paradoxes that remind those of Oscar Wilde. Toby admits, "I know very little about music, only just enough to know that I know what I like" (53-54). According to Victoria, "the Americans lack time to think about other things. Miners can't get it and millionaires can't use it. ... The poor have to think about money and the rich can think of nothing else" (117). Lady Raeburn assures everybody, "It is only necessary to marry once" (127). Metaphors are deftly used. "Helen tried to drag the discussion out of the clutches of her mother-in-law" (55). "Maps are anthologies for poets" (68). The connection between life and death, or between happiness and unhappiness is a favourite topic for discussion and ratiocination. "Unhappiness is the only synonym for happiness, isn't it?" (149). Life is the gift made by death to Isobel.

Still, in spite of its lexical brilliance, the salon conversation is just a verbal exchange: "It is so tiring to talk lightly about one thing when you are thinking deeply about something else" (38). The life of these people is marked by dinners and parties. Organizing them becomes a fundamental concern, a way to divide time and one's lifetime. Helen considers that in order to organize a successful party she needs four lists of guests: duty, pleasure, habit, and irresolution: "Irresolution is by far the most productive" (88). In the last list are included people who could bring a surprising element in the apparently smooth and predictable atmosphere. Helen "examined the cumulative effects of flowers and jewels and wine and noise ... while here and there a little pause filled by some glance or smile would give to a budding attraction a deepening touch of intimacy" (93-94).

Everyone is submitted to the most inquisitive scrutiny during these parties. The slightest change is cut and extensively commented upon because there is nothing else to do. Here is for instance, Helen. Amid the whirl of the party, she "danced and danced, shutting her eyes, trying to imagine that his [Toby's] arms were round her, trying to keep his kiss on her lips" (105). At the same time, the Ambassador comments with "authoritative melancholy, "I have never seen anyone like her. Beautiful, radiant, glowing and without adventure" (105). For Helen life "is a most wonderful journey" (206), experiences are taken one by one as they come. The essence of her moral code is to accept what life offers. Selina, another member of her circle, brings clarifications: "Surely life is a journey with people getting in and out of your carriage and yet nobody getting in and out of your carriage and yet nobody going to exactly the same place, by exactly the same route" (218).

Certainly, some characters are more prominently pictured than others. Matrimony gives Helen no satisfaction, not even a child: "At twenty-two, after four years of marriage, she was just what she had been at sixteen -uncommitted" (49). Some matrimonial sexual deficit is suggested with elegance: "she revelled in his mind, she delighted in the flavour of his personality - of all of which he was forlornly, impotently conscious" (8). Cyril's love is "an icicle from the equator" (129). The paradoxical expression points to some incompatibility that will increase in time. 
Toby is a young man with an erotic history in London's salons. Initially, he thinks that "it would be a great sacrilege to put his old love for Janet into the fancy dress of a grand passion" (208), then he is attracted by the difficulties of an adulterous relationship with Helen. Toby thinks that Helen has never been in love and he will have the privilege to teach her passion. The rivalry between this young man and the husband is metaphorically represented: "Also he had the feeling that Helen was the net over which he and Cyril were playing on an unmarked court, a game without rules" (38). On the other hand, Toby Ross and Helen Baldwin have complementary features that facilitate their romance. Toby "loved a touch of hardness. He thought that women should be like jewels, not flowers, and men like petals, not plants" (210). The bystanders of their affair notice these correlatives: "Helen would be ideal - lovely and womanly and brilliant and serene and invulnerable, clever enough to fascinate Toby, charming enough to enslave him, gentle enough to soften him, aloof enough to spur him on, kind enough to let him down gently. Helen [is] unattainable and accessible, warm and sympathetic and patient, but capable of being immensely caustic and uncompromising" (217-218).

Cyril, the husband, married late. He had reached the age of forty and the only woman in his life had been his mother. ${ }^{12}$ Bibesco discreetly suggests a very possessive matrimonial relationship between Helen and Cyril. Helen keeps asking her husband to tell her that he loves her but he is shallow and insensitive: "Does it need saying? / Everything needs saying hundreds and hundreds of times. / $\mathrm{He}$ looked at her with narrow, unsmiling eyes. 'I love you,' he said, and getting up to look for a book, he lit a cigarette" (29).

Matrimonial sex is an obligation deprived of passion: "She lay acquiescent. And then, with bitter self-reproach, she blamed her own ungenerous joylessness, while all the time she knew only too well that it was not herself that she was giving to him" (87). After a holiday in Scotland, Cyril realizes that in his marriage sexual intercourse meant nothing. It was just the selfish acceptance of "a generous, loving gift" (238) about whose source he never wondered: "His life had been the harbour in which Helen had sought refuge. He was proud and humble that she should have found it there. But perhaps she had wanted more than a harbour and perhaps he had been too proud and too humble to give it to her" (238).

Both the husband and the lover try to dominate Helen. Women's control by men is considered an inherent feature of civilized society. Toby draws "her lips into his, hard and masterful and greedy" (105). According to Bibesco, men's domineering nature has very deep roots, it is the expression of their sexuality and it is stimulated by the societal arrangements of patriarchal society. In the end, all characters, and particularly men, realize that "[i]t is so difficult in life to find anything beyond conquest and beyond possession" (103).

12 There are dangerous similarities with Antoine Bibesco, whose mother, Hélène Bibesco had been one of the grandes dames of Paris in the 1850 s. 
The tragedy is that adultery is not the solution. It only soils and erodes the self. The possible physical satisfaction cannot justify this maculation, a kind of death of the soul: "in our heart of hearts we knew that in the turmoil of the future lies nothing but broken hopes and raging doubts and -at the end, perhaps- an aching world?" (121). The reader can easily detect here the influence of Chekhov, particularly of his famous short story "The Lady with the Dog". The novelists and short story writers of the 1920's were very much under the influence of the Russian classics (Dostoyevsky, Turgenev, Chekhov). They were translated into English during this period by Constance Garnett and Samuel Koteliansky. We do not know for sure if Bibesco had read Chekhov's short story but Helen seems to have been responsive to the profound moral lesson given by the Russian writer. She prefers to remain "a water-lily rooted in some calm, unfathomed depth of water" (73), she is aware that this affair is temporary. She warns her lover, "Your passion will not survive the test of your ideals and your ideals will not survive the test of your passion" (191). Helen does not want to dominate Toby, she "had preserved his freedom intact for him" (169), but wanted "to be not 'a woman' but 'woman' ... perhaps a bigger, more important function of life than just to be herself" (192).

Her out-of-marriage experience will be a sad lesson: passion does not give much and cures nothing. "It was only through bitter disillusionment that she was to learn that intellect is not a guard against passion or physical fitness a guarantee of it" (126). In order to give a mise-en-abime ${ }^{13}$ to Toby and Helen's adulterous love story, Bibesco presents another couple as well: Virginia and Matthew. Their relationship is depicted in colourful nuances that remind the reader of maritime impressionistic paintings studded with an exquisite metaphor: "Virginia in apple green, lay on a golden beach throwing pebbles into a bright blue sea with a frayed edge of foam. Matthew, his pale gray eyes paler than ever in the brownness of his face, was wrapping her up with his smile. And even if she had tried to, her face had completely failed to keep the secret that he loved her" (234).

The amorous plot is influenced by the norms of courtly love. The kiss is an extremely important gesture that promises more intimacy, but the promise is all. Awaiting the sexual union is enough, the utmost pleasure is in the lover's imagination. When Helen crept into her room alone, having refused more intimacy with Toby: "the air smelt of jasmine, his arms were around her, his eyes were smiling into hers, his burning lips were on her mouth cooling the fevers inside her and ... there was tomorrow" (106).

The love affair between Toby and Helen has grown from the human being's normal needs of genuine affection, "this love of hers which had grown like a flower in the night, accepting its life simply, as a matter of course, without doubts or challenges" (142). As this bond grows, Helen becomes more and more maternal, while Tony gets more and more infantile: "When she said something her voice was low and chanting as if she were singing him a lullaby" (167). Finally, Toby

${ }^{13}$ Story within story, background against another background. 
himself pushes Helen back into her husband's arms because he does not want to be domineering. On the other hand, Helen is not sure whether she wants a new kind of relation being somehow too addicted to the traditional bond between man and woman: "His hold on her was relaxing. She could feel him almost falling away from her. ... She had preserved his freedom intact for him!" (169).

The relationship between Virginia and Mathew is not a model for Helen: "You don't want your lover to fall into your life like a coin into a money-box, to sing a song of yearning from his cage" (268). The novelist is able to suggest very delicately that society limits and even contradicts woman's freedom and desire to communicate. In the end, Helen remains isolated in a house and a garden which she populates with her memories. Her marital relationship is physical and not emotional. Some resemblance with Bibesco's matrimony is not impossible. Helen returns to her husband whom she loves "in every way except the one way, the only way that could help her" (270). The woman's body does not respond to her feelings and her feelings do not correspond to the impulses of her body. The novel ends with the two lovers' separation. Helen feels she is "a guest caught for life" (270) in her matrimony. Alienation is not painful, but soothing. All the characters are the victims of harrowing fatalism; the possibility of freedom is ridiculed: "To be a puppet with strings pulled by some invisible code was in a way less ridiculous than to pirouette about at your own initiative" (43-44).

Social problems are rather suggested, but they are not absent altogether. For instance, Bibesco mentions the inequality between man and woman as far as inheritance is concerned: "... if he [Lord Horsham] had a son, everything would be inherited by a tiresome cousin with an odious mother" (44). The Bank President, one of Helen's eternal guests, whom the writer does not consider necessary to name is sure that matrimony "is the highest ideal for a woman" (198) and that it brings beauty in a woman's life. Helen tries to move the discussion on another territory as she considers that "beauty is spiritual" (199).

Bibesco pays a lot of attention to women's condition. She is no feminist but she is a great observer. Woman's destiny is, after all, marriage. Lydia is a good example in this respect:

Lydia was forty and her hair was fading, rather than changing, from fair to grey, while the lissomness of her figure had drifted into a sort of irresolute thinness. It is a terrible thing, that steady drain of spinsterhood, how, not having children and illness and anxiety and quarrels gradually turns out the colours in a woman, though the most dissolute 'personal' life, marriage to a drunkard or a bully or a gambler nevertheless leaves the lamp lit, eyes able to shine, lips eager to smile. (101).

The women depicted by Bibesco are not independent, self-asserting individuals. They realize that society and cultural ways offer men more advantages, but ideologically feminism is not their choice. On the other hand, they long for a relaxation of mores. Lydia wonders why a single woman like herself "should not be entitled to at least one child without loss of reputation" (199). Victoria appreciates autonomy, but does not want to pay its price: "The point is that I am absolutely my own mistress. It is the most tiring thing in the world" (187). 
All Bibesco's novels are a kind of debate on the Eros, a sort of 1920's cors amoris. ${ }^{14}$ Types of femininity are discussed with more or less competence and a streak of irony. The English woman "gives herself completely. There are no reserves. It is as if a fish not only swallowed the bait, but tried to climb up the line" (107). Helen wants to give herself to a man and get fulfilment through her partner but she realizes that -sadly- love is, in fact, not directed towards the Other, love is ipsism. Love is self-love: "lovers are so indifferent, so unintimate. They don't see the other person because the other person is simply their own passion" (218). The constraints of masculinity are suggested with feminine delicacy. The metaphor encounters the paradox: "'Why is it important to be hard, Toby? Please tell me. I long to know.' I 'It is a sort of athleticism,' he said, 'it prevents one giving way.' / 'It is a substitute for being strong,' she said. / 'No. It is strength -a great strength'” (165).

Bibesco's writing also suffered some influence from Proust. Beauty is a communicative target; wording is carefully selected and filtered. Toby is "brilliant and brittle, like air waiting to fill a balloon before sailing away into blue horizons of distant hopes" (59); "the memories of the night before would evaporate in the drowsy July afternoon, lulled into forgetfulness by the humming of the humble bee" (175). "The 'beloveds' and 'darlings' and 'blesseds' belong to everyone, they are the ordinary currency of love, blank cheques with changing signatures" (74). Like Proust, her great friend, Bibesco plays with memories and tries to understand the process of remembering, connect it to physical sensations. Helen's Court, the main character's residence, "may be haunted by the ghosts not of people but of flowers" (187). Handwork, a traditional feminine activity, is used as a metaphor of time: "every hour festooned with garlands of delight" (266).

There are in Bibesco's novels a lot of cultural and intertextual references. Only her preference for psychological investigation is modernist and The Fir and the Palm is no exception. For instance, the discussion between Toby and Helen about the beauty of a view is similar to the revisitation of a famous scene from the novel Room with a View by E.M. Forester: "And the view,' she asked, 'mustn't one look at the view?' / 'Yes, and away from it"' (166). Literary impressionism and especially Virginia Woolf's fascination with light constitute the hypotext of the following passage: "he [Toby] could not write her a note because in the circumstances a note would irrevocably become a love letter - a few words shining like lamps, glowing with an ultimate brevity which he was very far from desiring" (136). ${ }^{15}$ The characters' moods are rendered by luminescent elements. "She turned the full light of her happiness on to Ned, talking to him..." (138). "He could feel her quivering with response, like a moon trembling in the ripples of a pool" (141). Tony's feeling for Isobel is "shimmering adoration" (104). Light is the raw material for the impressionist painter and writer: "Curling amber lights in her hair and laughing amber lights in her eyes

${ }_{14}$ Debates about (courtly) love, presided by the grand ladies of early Middle Ages.

${ }^{15}$ My emphasis. 
-smiles playing hide and seek all over her face, peeping under half shut lights and re-emerging triumphantly through open lips" (159).

In conclusion, The Fir and the Palm deals with life, death, and love. The contrast between the intensity of the characters' experience and the insensitive world that goes on and on as if nothing had happened is a main theme: "It is so callous of the world to go on without even a pause, one tiny moment to show you it knows that nothing will ever be quite the same again" (286-287). Helen and Cyril will continue their matrimonial existence. Helen's erotic bypass with Toby will be forgotten.

Some of the issues from The Fir and the Palm will be resumed in There is No Return, the second novel written by Bibesco during the 1920s, but the emphasis in the latter is upon the confrontation with death. Isobel, the main character, is in hospital dying with an incurable disease. It is the moment when one sums up. Helen's monologues or her discussions with her loved ones point to her profound regret for everything she has not experienced: "Why should I think of things to wait undone when there is so much that I shall never do?" (1927, 10); "I regret every temptation that I have resisted, every pain I have not felt" (11). It is painful to know for sure that "what you leave behind you will go on living -living its own life" (14). Bibesco is a very sensitive and compassionate painter of the body in illness: "Her eyes, her lips - nothing but shadows, even the undaunted brightness of her hair, a deep light in a deep shadow" (7). Convinced that "death is a part of life -of this life" (9), she rejects any suspicion that her considerations might be " $[t]$ he lament of a dead woman over her still living virtue" (11).

As in The Fir and the Palm, the matrimonial relation is unsatisfying. Ironically, Isobel words the incompleteness of her matrimony: "Anselm really had been a perfect husband. He had considered her, and loved her, and appreciated her, he had smiled with her and smiled at her. It was with those smiles, Isobel reflected, that he had kept her out of life, that he had sterilised her" (16).

Bibesco's message is that death is part of life and death is ours to the same extent as life is ours: "I regret every temptation that I have resisted, every pain I have not felt" (11). Doctor Ramsey ${ }^{16}$ and Nurse Gerard try to help her cross the border of this world painlessly. Their efforts are perceived differently by the members of the erotic triangle from this novel: Isobel, Anselm (the husband), and Tony (the lover). Tony taught Isobel what love really is because the husband enjoyed his marital rights, dominated her, but was not interested in the needs of the real woman called Isobel: "Without demanding anything from her, he had in a way taken everything both from and away from her. He had created her in his image, and to his creation he had been scrupulously devoted and infinitely considerate" (72). The education and the rules imposed upon Isobel make her wonder if she is actually made for love, if

16 Bibesco uses the proper name of the family from Virginia Woolf's novel To the Lighthouse which was published in 1927, the same year as There Is No Return. 
it is not her fault for all this. The simultaneity between this final disease and sex is too much to bear for her.

Some ladies pay visits to Isobel or haunt her past. Aunt Alicia, Lady Alicia Raeburn, or Helen Horsham remind Isobel of the superficiality of those lives wasted in the endless parties organized in London's salons. Lady Raeburn loves her nephew, Anselm, but she cannot help the couple mend what can still be mended in their relationship. Most of Isobel's visitors are, in fact, looking for a new topic for gossip, their interest in the patient is fake.

Isobel's disease surpasses the pathological. Nurse Gerard makes the subtle observation that Isobel is "a woman afflicted for the first time with a chronic, a mortal disease -life" (129). On the brink of death, Isobel remembers how she faced love for the first time; "when love comes, we long with bitter anguish for our lost virginity, we wish back that very ignorance which would have been a frustration of our love" (128). Now, in hospital, those around her, "they are taking" (17) her time and she does not have too much time.

As usual for Bibesco, she finds her inspiration in the life of the elites, those who do not care about making both ends meet but who experience suffering, nevertheless. Although she is well taken care of, even spoiled, Isobel is not allowed to live her life. Like the main character from Charlotte Perkins Gilman's short story The Yellow Wallpaper, Isobel has to live in submission to conventions. The pathology of both characters is not only a matter of the body but rather the result of the connection between the mind and the body. Women are pushed toward minute and petty activities which bring no satisfaction. They are considered fragile beings, who should not tire themselves. In the end, these constraints affect these women's body as well as their psychology. Society and the hegemonic patriarchal culture obliges women to "rest," in fact to develop no significant action and this repose will finally become "the final rest." They are told that they cannot seize the general aspect of things; they cannot rise above the insignificant. "At the best of times women didn't really much like general ideas, they always skated over them on an inside or an outside edge of the personal" (24). Is liberty possible for women? What does liberty mean for women? Bibesco is very aware that liberty comes with the price of solitude, at least in the world of the 1920's she knows and she describes in her novels: "The burden of our loneliness [is] handed gracefully to us on a salver" (73).

Feminism is considered by Isobel -and she is the spokeswoman of the authortoo noisy. It is an ideology on the brink of vulgarity because her social status, her wealth protects her from many gendered impositions: "Can it be true, the nonsense that is talked about the perpetual war between men and women? Are they inevitably ultimate enemies? Is it always a question of victory and surrender and occupation, of a vain attempt to defend your frontiers followed by an equally vain effort to lose them?" (77). Only love can bring peace between man and woman: "woman is nothing but a lamp lit until some flame of love has brought the torch that shines into the night" (87-88). She is also suspicious about the condition of professional women. Bibesco cannot get out of the sentimental frame of women's condition although she is sympathetic about her sisters regardless their class: "Remarkable women, useful women, professional women, unless they are also loved women, what are they but 
poor little trained animals taken from one music hall to another, forbidden to run lest they should forget how to walk on their hind legs?" (87).

The solution would be a complete rebuilding of life and society from the bottom. This idea is present more or less overtly in many novels of the 1920s. The victory of Bolshevism in the Soviet Union had given hope that a better society could be founded on the basis of this ideology. Bibesco is a subtle, discreet, but efficient critic of the upper classes although she does not insist too much on the material aspects of life. This would be considered too vulgar. Even if it is very late, Tony wants to get Isobel out of the conventional and expose her to real life: "he now wanted to fold her up into layers and layers of intense and conscious living" (42). It is thanks to him that Isobel will get rid of conventions and approach death reconciled with herself and with life.

In the best impressionist tradition, Bibesco plays with light and words wonderfully luminescent pictures as in The Fir and the Palm: "To see her going from guest to guest, coming down the long dimness like a light so that, as she passed them, the very flowers seemed to shimmer, sharing for a moment the secret of her radiance" (78).

Some of the characters from the 1924 novel reappear and reinforce the thesis of the novel: "Life is difficult, but death is far more difficult still" (22). Bibesco's modernist subjectivity relies on transient impressions which show the beauty of the world and life for ever flowing towards death. Lady Raeborn wonders: "[W] hy should fine impressions be more reputable than second thoughts?" (33). The rhetorical question is, in fact, a statement about Bibesco's preference for and use of impressions.

The novel has something of Madame de La Fayette's sober, restrained classicism. Time and space (in this case, the ward, the hospital) are hardly suggested. Characters spend their time thinking of the past. Death is feared, but also desired, for life means pain and risk: "While there is life, there is danger" (34).

Bibesco does not have the gift of long sentences like Virginia Woolf or Marcel Proust. Her style is closer to Katherine Mansfield's epiphanies, short sentences which end up with suspension points because emotions are too powerful to be expressed verbally.

Contaminated by Proustian aestheticism, which is so powerfully expressed in the correspondence between Antoine Bibesco and Marcel Proust, the novelist Elizabeth Bibesco creates characters for whom human existence and art have the same measure: beauty. For instance, Tony expresses his erotic feelings in relationship with aesthetic values. "He thought he had chosen her among women, but he had chosen her among masterpieces" (47). Bibesco tends to construct abstract metaphors with concrete words. Tony is at hospital visiting Isobel and he wants "to fold her up into layers and layers of intense and conscious living" (42). Sophisticated aestheticism combines with the minute description of the sick body: "When she stretched out her fingers, they lay like shadows on her lap" (54). Isobel envisages suicide but then she changes her mind: "Suicide can never be anything but a desertion and she, Isobel, was not deserting, she was fulfilling some old contract, honouring an unwritten obligation" (184). As death approaches, Isobel 
feels that she already knows what is to be known. Her experience is translated into the challenging form of paradox: "Later we learn to ask no questions in order to be told no truths" (184).

The approach of death clarifies, changes the relations between the spouses: "Ever since she had told him that she loved Tony he had unconsciously begun to think of her less and less as a possession" (56). The husband needs the confirmation of adultery in order to realize oppression of the traditional matrimonial rules. The allusions to courtly love and its conventions are very clear: "She would give both her hands to him [Tony], and he would kiss them and thank God very reverently for all His mercies. ... It was only on his knees that he had contemplated her -the image in which he had created her was altogether sacred" (60-61). The tragedy is that male desire can only be fulfilled by possession and for the husband this is an increasing feeling. Anselm looks at his dying wife and "he felt an infinite sense of possession" (188). Death brings her together both with her lover and her husband: "At last they were together" (190). The trio! The erotic triangle! Actually Isobel moves, as an object of desire, from the husband to the lover, but the impossibility of sexual contact enrages Tony: "She didn't realize how the knowledge that she loved him must inevitably prevent him from having a moment's peace until he possessed her, that he would never be able to be considerate and tender again until she belonged to him" (63). Paradoxically and tragically, Tony's desire to know her body intensifies as disease destroys her more and more. Bibesco shares with Freud (1950) the conviction that satisfied desire resembles death: "There is nothing so dead, so dull, so lifeless, as satisfied senses ... But what a good thing to know that nothing is permanently necessary, that holes fill up, that wounds heal" (Bibesco 1927, 83, 156).

Two years after Isobel's death, Tony got engaged and "Anselm sent his betrothed Isobel's diamond chain. The young lady was at the age when one believes in significance" (191-192). Life goes on. Everybody moves on. Dr. Ramsey, who took care of Isobel, retires. Lady Raeburn sums up Isobel's life: "Quite suddenly everything seemed to matter to her" (192). The moment of death made her realize the vacuity people of her class lived in.

Social issues, like the life of the working class, appear very discretely in this novel but this does not mean that Bibesco is selfishly unaware of these milieus. For example, Isobel feels deep compassion for the Japanese waiters who serve at Claridge's because an earthquake had made a lot of victims in Japan and the waiters' loved ones may be in danger thousands of miles away. Death connects all humans, be they rich or poor. We all die, in the end. But it is better if, at least, we die surrounded by the affection of our loved ones and we do not face our final moments in solitude.

It is beyond doubt that Elizabeth Bibesco's novels of the 1920s show that the princess had a voice of her own. She does not roar, but she does deal with important truths. Bibesco's fiction must be considered in the context of British literary impressionism, in a literary sisterhood that connects her to Virginia Woolf or Katherine Mansfield. A novelist of the upper classes, Bibesco convinces us that, whether rich or poor, life is the same in its essence for us all: superb in its incompleteness. A writer of remarkable prolificacy -she has left novels, short stories, 
essays, children's literature, journalistic articles- Elizabeth Bibesco deserves more attention than she has ever received till now. ${ }^{17}$

Reviews sent to the author $13 / 01 / 2022$

Revised paper accepted for publication 20/01/2022

${ }^{17}$ See Mudure 2020: "Elizabeth Bibesco: o prinţesă între Anglia și România” ["Elizabeth Bibesco: A Princess between England and Romania"]. 


\section{WORKS CITED}

Apollinaire, Guillaume. 1992. Amorurile unui hospodar. Translated by Emil Paraschivoiu, preface by Ovid S. Crohmălniceanu. Bucharest: Efemerida.

Bibesco, Marthe. 1970. “De François Mauriac à Marcel Proust.” Revue des Deux Mondes 12 (Dec.): 533-546.

Bibesco, Elizabeth. 1924. The Fir and the Palm. London: Hutchinson.

Bibesco, Elizabeth. 1927. There Is No Return. London: Hutchinson.

BLow, Simon. 2004. "Priscilla Bibesco." The Independent, 27 Nov. Accessed 10 Jan. 2022. http:// theesotericcuriosa.blogspot.com/2010/12/family-profile-triptych-grandmother.html.

Brindle, Kym. 2020. “'Mysterious Epistles': Letters Home in Katherine Mansfield's Short Stories.” Journal of New Zealand Literature 38 no. 2: 15-35.

Chenhov, Anton. 2004. "The Lady with the Dog." Translated by Constance Garnett. Accessed 10 Jan. 2022. https://www.gutenberg.org/files/13415/13415-h/13415-h.htm\#THE_LADY_ WITH_THE_DOG.

Ferguson, Suzanne C. 1979. "The Face in the Mirror: Authorial Presence in the Multiple Vision of Third-Person Impressionist Narrative.” Criticism 21 no. 3 (Summer): 230-250.

Freud, Sigmund. 1950. Beyond the Pleasure Principle. Translated by James Strachey. London: The Hogarth Press \& The Institute of Psycho-Analysis.

Grenville, Anthony \& Andrea Reiter (eds.). 2011. Political Exile and Exile Politics in Britain after 1933. Amsterdam and New York: Brill.

Hodgson, Priscilla. 1975. "Ma grand-mère: Margot Oxford." Revue des Deux Mondes. January: 99-105.

Meyers, Jeffrey.1978. “The Quest for Katherine Mansfield.” Biographie 1 no. 3 (Summer): 51-64.

Middleton Murry, Katherine. 1986. Beloved Don Quixote: The Unknown Life of John Middleton Murry. London: Souvenir Press.

Mudure, Mihaela. 2020. "Elizabeth Bibesco: o prinţesă între Anglia şi România." In România în spațiul euroatlantic: interferenţe culturale şi lingvistice, edited by Ofelia Ichim (coord.), AlinaMihaela Bursuc, Marius-Radu Clim, Ofelia Ichim, Veronica Olariu, Ana-Maria Prisacaru, Ioana Repciuc, 465-482. Bucharest: Editura Tracus Arte. Accessed 3 Jan. 2021. https:// www.philippide.ro/pages/Romania\%20in\%20spatiul\%20euroatlantic.html.

MuicA, Alexandra. 2017. "Introduction to Elizabeth Bibesco's Literary Works." In Cultural Texts and Contexts in the English Speaking World V, edited by Teodor Mateoc, 34-40. Oradea: Editura Universităţii din Oradea.

Palewski, Gaston. 1974. “Propos.” La Nouvelle Revue des Deux Mondes, January: 120-129.

Perkins Gilman, Charlotte. 1999. The Yellow Wallpaper. Accessed 11 Jan. 2021. https://www.gutenberg.org/files/1952/1952-h/1952-h.htm.

“Princess Bibesco Dies in Bucharest.” New York Times, 9 Apr. 1945. https://www.nytimes.com/ 1945/04/09/archives/princess-bibesco-dies-in-bucharest-author-daughter-of-late-lord.html.

Proust, Marcel. 1919. Pastiches et mélanges, edited by Bourlapapey, Bibliothèque numérique romande. Accessed 20 May 2020. https://ebooks-bnr.com/ebooks/pdf4/proust_pastiches_et_melanges.pdf. 
Schumann, Maurice.1984. "Gaston.” Revue des Deux Mondes. October: 3-7.

Vernière, Paul. 1971. "Proust et les deux mémoires." Revue d'histoire littéraire de la France 5-6 (Sept.-Dec.): 939-949. 
